\title{
Frufous System: A Simple Water Purifier with Hydro Filter Tool
}

\author{
I. Kusumawati ${ }^{1, *)}$, Juhari ${ }^{2}$, Suryati ${ }^{3}$ \\ STKIP Singkawang, Singkawang, Indonesia \\ intank@stkipsingkawang.ac.id ${ }^{1}$, juhari@gmail.com ${ }^{2}$, suryati@gmail.com ${ }^{3}$ \\ ${ }^{*}$ Corresponding author
}

Keywords:

Hydro Filter Tool, Filtering,

Pollution, Frufous, Water

Purifier

\begin{abstract}
Water pollution is a change condition in a water reservoir such as lakes, rivers, oceans, and groundwater due to human activities. This pollution causes many aquatic organisms to die and causes various diseases. Based on these problems, a solution is needed to deal with water pollution. The solution was given in the manufacture of a simple water purifier that can be used at home, namely the Frufous water purifier system. The method used in this research was research and development $(R \& D)$ with a level of difficulty at level 1 , namely researching without testing the product. The product was researched and developed as an alternative water filter by applying the Frufous system (From Us For Us). Validation of this product was carried out internally in a Focus Group Discussion (FGD). The product had been repaired according to the judgment and suggestions of expert and practitioner opinions. The product design had been declared internally tested. The results of this research and product development showed products that are original, functional, complex, and authentic. The Frufous water purifier system was complex so that it could filter dirty water into clean and clear water, compared to being untreated/filtered. This research was expected to be used as an inspiration for research ideas to be applied at an advanced level of difficulty, which can be tested externally and applied en masse.
\end{abstract}

\section{INTRODUCTION}

Water is essential for survival. Decreasing water quality due to human activity which causes changes in water conditions to become worse in water reservoirs, such as lakes, rivers, oceans, and groundwater is a frequent phenomenon. Water has the property of easily dissolving other substances, so water is very easily contaminated by substances that pass through it. This pollution has an impact on the survival of organisms and microorganisms that live in water and causes various diseases, as well as the need for clean water for activities of daily life (Agustiningsih \& Sasongko, 2012). In PP No. 20 of 1990 concerning Water Pollution Control (Article 1, point 2) is defined that water pollution is the entry or inclusion of living things, energy substances, and or other components into the water by human activities so that the quality of the water decreases to a certain extent which causes water is no longer useful according to its purpose (Government Regulation, 1990). Water quality is influenced by the quality of water supply originating from the catchment area, while the quality of water supply from the catchment area is related to human activities in it. Various human activities to meet their daily 
needs originating from the industrial, household, and agricultural activities will contribute to the decline in water quality, especially in rivers. In addition, deforestation for agricultural land clearing, housing, and other building construction also results in groundwater contamination (Widiyanto, Yuniarno, \& Kuswanto, 2015). Industrial pollutants such as organic pollutants (liquid waste), inorganic pollutants (heavy metal solids), fuel residue, kerosene, and oil spills are the main sources of water pollution, especially groundwater (Widiyanto, Yuniarno, \& Kuswanto, 2015). Liquid waste generated by various small industries such as the organic fertilizer industry, tofu, and soy sauce factories and the shredding of plastic pellets has the potential to pollute the environment. In addition, industrial waste is very potential as a cause of water pollution. For example, to give a little idea of how much water pollution by industrial activities in Singkawang City has been tested on the quality of wastewater based on the Central Statistics Agency of Singkawang City on Industrial Liquid Waste Quality Data in Singkawang City, as shown in Table 1 (BPS, 2018).

Table 1

Industrial Liquid Waste Quality Data in Singkawang City

\begin{tabular}{|c|c|c|c|c|c|c|c|c|}
\hline \multirow[b]{2}{*}{ No. } & \multirow[b]{2}{*}{ Parameter } & \multirow[b]{2}{*}{ Unit } & \multirow[b]{2}{*}{$\begin{array}{c}\text { Quality } \\
\text { standards }\end{array}$} & \multicolumn{5}{|c|}{ Observations at the outlet point } \\
\hline & & & & $\begin{array}{c}\text { Kangaroo } \\
\text { Soy Sauce } \\
\text { Factory }\end{array}$ & $\begin{array}{c}\text { Micky } \\
\text { Soy } \\
\text { Sauce } \\
\text { Factory }\end{array}$ & $\begin{array}{c}\text { Plastic } \\
\text { pellet } \\
\text { processing } \\
\text { plant }\end{array}$ & $\begin{array}{c}\text { Factory } \\
\text { tofu } \pi \\
\text { satellite }\end{array}$ & $\begin{array}{c}\text { Decision MENLH No. } \\
\text { KEP. } \\
\text { 51MENLH/101995 } \\
\text { attachment C about } \\
\text { wastewater quality } \\
\text { standards for } \\
\text { industrial activities }\end{array}$ \\
\hline 1 & Color & TCU & 50 & - & - & 112 & - & \\
\hline 2 & Nitrite & $\mathrm{Mg} / \mathrm{l}$ & 0.1 & - & - & 1.2 & - & \\
\hline 3 & Total Fosfat & $\mathrm{Mg} / \mathrm{l}$ & 0.2 & - & - & 0.46 & - & \\
\hline 4 & TDS & $\mathrm{Mg} / \mathrm{l}$ & 2,000 & 85,000 & - & - & - & \\
\hline 5 & $\mathrm{Ph}$ & - & 6.9 & 5.45 & - & - & - & \\
\hline 6 & BOD & $\mathrm{Mg} / \mathrm{l}$ & 30 & 648 & 360 & 47 & 161 & \\
\hline 7 & COD & $\mathrm{Mg} / \mathrm{l}$ & 80 & 4210 & 470 & 72 & 247 & \\
\hline 8 & $\mathrm{H} 2 \mathrm{~S}$ & $\mathrm{Mg} / \mathrm{l}$ & 0.05 & 0.6 & 1.6 & - & - & \\
\hline 9 & Fenol & $\mathrm{Mg} / \mathrm{l}$ & 0.5 & - & 0.5 & - & 0.60 & \\
\hline 10 & TSS & $\mathrm{Mg} / \mathrm{l}$ & 200 & - & 295 & - & - & \\
\hline
\end{tabular}

Based on Table 1, it is necessary to develop an alternative tool as a solution to the problem of water pollution, so that water can be reused by the community. So far, many tools have been developed to filter water, ranging from simple to sophisticated ones. The tool developed is a combination of the two and is an innovation that has never existed before. This alternative water filter tool developed uses the Frufous system (From Us For Us). Frufous is designed in such a way that it is complete and ready to filter even high levels of impurity because the filtering system is made complete with the addition of several components in it. This water filtration system is a system with a precise and complex design to provide benefits and meet community needs for clean water. Through the application of the Frufous water filtration system, it is hoped that the community will have no trouble getting clean water.

The Frufous water filtration system can filter the dirty water into clean water with a high level of cleanliness, this is because this filtering system uses two stages of filtering. The two stages of filtering can filter solid impurities using a conventional system and impurities that are invisible to the eye such as bacteria using a modern system. With the innovation of the Frufous system, it is hoped that it can meet the decreasing supply of clean water in the Singkawang city and can provide clean water for all people. This research aims to provide solutions related to reduced clean water supply and to recycle dirty water into clean water so that the ultimate goal is the fulfillment of clean water supply for the people of Singkawang city.

\section{METHOD}

The method used in this research is the method of development research (Development Research) in 
which there is a product design (Yuberti, 2014) with the development model of Borg \& Gall (2003). However, in this study, the research and development method carried out was at the level of difficulty level 1, namely researching without testing the product (Sugiyono, 2016). The development of this product is limited to internally tested stages which are validated by experts and practitioners. Making a product starts with potentials and problems, then a product design is made, which is then presented in an FGD (Forum Group Discussion) in the form of a video presentation and a sketch of the design of the tool design manually. Furthermore, experts and provide input and suggestions for product improvement, and the product is repaired according to these suggestions. After the product has been revised, the product is declared to be tested internally. Data analysis of the resulting product design is based on the validation results of the feasibility score. Analysis of the data from the resulting product design based on the results of the validation of the feasibility score expressed by the equation (Arifin, 2012).

$$
\text { the eligibility score }=\left(\sum \mathrm{x} / \sum \mathrm{s}\right) \mathrm{x} 100 \%
$$

information: $\quad \sum \mathrm{x}=$ score obtained

$$
\sum \mathrm{s}=\text { maximum score }
$$

Based on the results of the calculation of the score, then interpreted in the eligibility category (Azhari, 2017) with a slight change, as shown in Table 2.

Table 2

Interpretation Category Frufous

\begin{tabular}{cl}
\hline Score Interval $(\mathbf{x})$ & \multicolumn{1}{c}{ Interpretation Category } \\
\hline $77,6 \%<\mathrm{x} \leq 100 \%$ & Frufous System design is worth making and testing \\
$55 \%<\mathrm{x} \leq 77,6 \%$ & Frufous System design is worth making and testing after \\
& repairs \\
$33,3 \% \leq \mathrm{x} \leq 55,5 \%$ & Frufous System design is not yet worth making and testing \\
\hline
\end{tabular}

\section{RESULTS AND DISCUSSION}

The water filtration system is designed and manufactured by considering the effectiveness of the equipment, the efficiency of the equipment, and its use. The use of the filtering process is given great attention so that it makes it easier and helps the community to get clean water and reduce water pollution. Making clean water can be done by utilizing filtered rainwater (Handarsari, Hidayah, \& Sya'di, 2017). Research on the filtration of dirty water into clean water has also been carried out by producing a filtration device (Susanto, Kalsum, \& Yanolanda, 2014; Untung, 2011). Fig. 1 is the design of a dirty water filtering system to make water suitable for use, which is named Frufous (From Us For Us).

The information in the water filtration system design according to the picture is as follows: (1) Home; (2) Hose to drain dirty water from the house; (3) The flow of clean, filtered water to the house; (4) Sewer where dirty water is collected from the house; (5) Aluminum trash filter; (6) Pump; (7) The dirty water reservoir as well as the first stage water filter; (8) The water reservoir from the first stage of filtering; (9) Clean water reservoir resulting from the final filtering process; (10) Hydro Filters; (11) The backwash storage well of the Hydro Filter; (12) Iron support for dirty water reservoirs making a prototype and water filtration system following the concept and design using the necessary tools and components. In principle, the results of the manufacture of this water filtration system are carried out starting from the household water filtering stage. After the final result is obtained, the filtered and purified water is tested in the laboratory, if it meets the clean water standard requirements, it can be used for daily needs. However, these tests will only be carried out on external tests intended to be 
applied en masse. However, in this study, product trials were not carried out at that stage.



Fig 1. Frufous water filtration system design

This research was only carried out by making product designs for internal validation only, and it was declared valid by experts and practitioners in the revision of product improvement suggestions that were made. The results of this validation found a feasibility score of $82 \%$ which means Frufous System design is worth making and testing Other research has also been carried out on the design of polluted water purification equipment (Syaputra, Sugianto, \& Syech, 2015) with a different form and analysis from this research, but in the same context, namely designing a water purification device.

Based on the validation test, it can be concluded that the product is declared original, functional, complex, and authentic. These various things are described as follows: (1) Original, the device is a new product that has high novelty and innovation value, there has never been a similar product by applying two-stage filtration like this Frufous system; (2) Functional, this tool is said to be functional because it has a very good function if it has been tested externally because this tool is capable of being a solution to the problems of people who experience clean water difficulties due to water pollution in the surrounding environment; (3) Complexity, the Frufous water filtration system is a complex water filtration system. This is because in this filtering system there are two stages of filtering.

The first stage is the stage of conventional water filtering using simple ingredients but proven to be able to filter dirty water. In the first stage, dirty water from household waste is flowed into a ditch and then pumped into the first filtering basin. In this first filtering tub, the filtering process begins using easily available materials such as gravel, coconut husk, charcoal, fibers, and sponges, then the semiclean water is obtained from the filter. To ensure that the water is spotless and safe to use, the second stage of water filtering is used. This second stage using a modern water filter called the Hydro Filter. This filter tool besides filtering water also purifies the water and kills the bacteria contained in the water. From the second stage of the filtering process, clean, clear, and healthy water is obtained, meaning that the water has met the requirements for suitable water. Then this clean water is channeled back to the residents' houses for their daily needs. This is the concept of this water filtration system, namely from us for us (from us for us) so that this filtering system is named Frufous; (4) Authentic, the tool developed can be said to be authentic because it can be a consideration for the solution of PP. 20 of 1990 concerning Water Pollution Control (Article 1, number 2) (Government Regulation, 1990). 


\section{CONCLUSIONS}

Water is a source that is needed in our lives. However, with the times, clean water is decreasing due to water pollution or water pollution. Water pollution causes quite alarming impacts because both plants, animals, and humans are affected by this water pollution. Therefore, we need a solution to overcome and reduce this water pollution. This is what motivates the author to create a complex water filtration system, from dirty water to clean, clear, and healthy water so that it can be used for the daily needs of residents. This water filtering system adopts the concept of from us for us so that this water filtration system is named Frufous which is the conclusion of from us for us. With the Frufous filtering system, it is hoped that it will make it easier for people to get clean water. In addition, adopts the concept of from us for us, this research also uses a concept with two stages of filtering, namely conventional filtering system and modern filtering system. With this water filtering system, clean water can be produced which can be used to meet the needs of clean water for the people of Singkawang city following the purpose of this research, namely to provide solutions related to the reduced supply of clean water in the Singkawang city.

\section{REFERENCES}

Agustiningsih, D., \& Sasongko, S.B. (2012). Analisis Kualitas Air dan Strategi Pengendalian Pencemaran Air Sungai Blukar Kabupaten Kendal. Jurnal Presipitasi, 9(2), 64-71. https://doi.org/10.14710/presipitasi.v9i2.64-71. (Accessed on June 2, 2020).

Arifin, Z. (2012). Penelitian Pendidikan Metode dan Paradigma Baru. Bandung: Remaja Rosda Karya.

Azhari, M.V. (2017). Pengembangan Template Media Pembelajaran Sebagai Sarana Presentasi Mahasiswa dalam Mata Kuliah Seminar Tata Boga. Universitas Pendidikan Indonesia.

Badan Pusat Statistik (BPS). (2018). Data Kualitas Limbah Cair Industri di Kota Singkawang. www.bps.go.id (Accessed on May 18, 2020).

Borg, W.R. \& Gall, M.D. (2003). Educational Research: An Introduction 4th Edition. London: Longman Inc.

Government Regulation. (1990). Government Regulation No. 20/1990 on Water Pollution Control. https://leap.unep.org/countries/id/national-legislation/government-regulation-no-201990water-pollution-control.

Handarsari, E., Hidayah, F.F., \& Sya'di, Y.K. (2017). Deseminasi: Pembuatan Air Bersih Dengan Memanfaatkan Air Hujan Melalui Penyaring Pipa Bersusun Berbasis Adsorben. Prosiding Seminar Nasional Publikasi Hasil-Hasil Penelitian dan Pengabdian Pada Masyarakat, September, 496-503.

Sugiyono, (2016). Metode Penelitian dan Pengembangan: Research and Development. Bandung: Alfabeta.

Susanto, D., Kalsum, T.U., \& Yanolanda, H.S. (2014). Alat Penyaringan Air Kotor Menjadi Air Bersih Menggunakan Mikrikontroller Atmega 32. Jurnal Media Infotama, 10(2), 142-150.

Syaputra, A., Sugianto., \& Syech, R. (2015). Rancang Bangun Alat Penjernih Air yang Tercemar Logam Berat $\mathrm{Fe}, \mathrm{Cu}, \mathrm{Zn}$ dalam Skala Laboratorium. Ekp, 13(1), 86-92.

Untung, Onny. (2011). Menjernihkan Air Kotor. Jakarta: Niaga Swadaya.

Widiyanto, A. F., Yuniarno, S., \& Kuswanto, K. (2015). Polusi Air Tanah Akibat Limbah Industri Dan Limbah Rumah Tangga. Jurnal Kesehatan Masyarakat, 10(2), 246. https://doi.org/10.15294/kemas.v10i2.3388. (Accessed on May 18, 2020).

Yuberti. (2014). Penelitian dan Pengembangan. ejournal.radenintan.ac.id. 68-70. (Accessed on May $18,2020)$. 